\title{
Adaptive abilities of the females and sustainability of ruminant livestock systems. A review
}

\author{
Fabienne BLANC $^{\mathrm{a} *}$, François BocQUIER ${ }^{\mathrm{b}}$, Jacques AGABRIEL ${ }^{\mathrm{c}}$, \\ Pascal D'HOUR $^{\mathrm{d}}$, Yves CHILLIARD ${ }^{\mathrm{c}}$
}

\author{
${ }^{\text {a }}$ Unité Élevage et Productions des Ruminants, ENITA Clermont, BP 35, Site de Marmilhat, 63370 \\ Lempdes, France \\ b Agro-M, UMR Élevage des Ruminants en Régions Chaudes, 2 place Viala, 34060 Montpellier \\ Cedex 1, France \\ c INRA-PHASE, Unité de Recherches sur les Herbivores, Theix, 63122 St-Genès-Champanelle, France \\ ${ }^{\mathrm{d}}$ INRA, UE des Monts Dore, Le Roc, 63210 Orcival, France
}

(Received 12 May 2006 - Accepted 26 September 2006)

\begin{abstract}
In a systemic approach, the breeder can be considered as the decisional component of the livestock system, whereas animals are usually depicted to be part of its biotechnical component. The animal itself is a biological system whose ability to survive, grow, reproduce and cope with the environnement and livestock practices play a major role in the ability of the livestock system to sustain. In such a conceptual representation of the system, the reproductive females draw a peculiar attention since they determine in a great part the productivity and the durability of the system through their abilities to maintain their own production level (milk production, numeric productivity) and to save their reproductive efficiency (repeated pregnancies and lactations) over years. Considering the animal level and its lifespan, it is clear that the abilities to adapt rely on behavioural and physiological regulatory processes. The study of the biological mechanisms involved in the adaptation to undernutrition is particularly interesting since regulatory processes implied in energy metabolism may interfere directly or indirectly with the reproductive function, and consequently, with the durability of the livestock system. A biological significance of such relationships between nutrition and reproduction is given that they allow the female to be informed about the associated risk of entering a productive process facing the uncertainty of the nutritional context. Although the general mechanisms implied in the ability to adapt to the underfeeding constraint are conserved among ruminants, the thresholds (or priorities) may largely differ according to the breed within the same species. Hence, in order to evaluate the ability of the ruminant livestock systems to perpetuate in hard environments (maintaining their production levels) or to assess sustainable objectives (opening bushy landscapes by increasing grazing pressure), animals' inherent adaptive potentialities have to be well known.
\end{abstract}

adaptability / nutrition / reproduction / perennity / livestock systems sustainability

\footnotetext{
*Corresponding author: blanc@enitac.fr
} 
Résumé - Capacités adaptatives des femelles et durabilité des systèmes d'élevage. Synthèse bibliographique. Dans une représentation systémique du système d'élevage, l'éleveur incarne la composante décisionnelle du système, tandis que l'animal constitue, avec la ressource, sa composante biotechnique. L'animal lui-même peut être considéré comme un système biologique soumis à un environnement contraignant, dont les aptitudes à survivre, croître, se reproduire et s'adapter jouent un rôle fondamental dans la pérennité du système d'élevage. Les femelles reproductrices tiennent une place particulière dans cette représentation car non seulement elles déterminent une large part de la productivité du système par leur propre niveau de production (production laitière, productivité numérique), mais elles en assurent également sa reproductibilité au cours du temps (investissement reproductif). A l'échelle de l'individu et de sa durée de vie, les modalités d'adaptation reposent sur des processus de régulations comportementales et physiologiques. De tels processus ont été particulièrement mis en avant par les études portant sur l'aptitude des femelles de ruminants à s'adapter à la contrainte nutritionnelle (comportement alimentaire au pâturage et aptitude à constituer et mobiliser les réserves adipeuses). L'adaptation à la sous-nutrition revêt un intérêt particulier pour la pérennité des systèmes d'élevage en milieux difficiles dans la mesure où les processus de régulation du métabolisme énergétique interviennent sur la fonction de reproduction et sont par ailleurs susceptibles d'informer la femelle, à des moments-clés de son cycle de production, du risque associé à l'enclenchement d'une nouvelle gestation. Si les mécanismes digestifs, métaboliques et hormonaux impliqués dans l'adaptation à la sous-nutrition sont identiques chez les ruminants, les seuils de réponse varient selon le génotype (espèce, race), révélant ainsi des différences de potentiel adaptatif. Par ailleurs, si certains échecs biotechniques peuvent être imputés à une moindre efficacité de la réponse adaptative, d'autres peuvent en revanche se révéler cohérents du point de vue du fonctionnement biologique de l'organisme et de la gestion de priorités telles que la survie de l'individu ou l'investissement maternel. Ainsi, lorsqu'il s'agit d'évaluer l'aptitude des systèmes d'élevage à être pérennes il convient en particulier d'avoir une bonne connaissance des potentiels adaptatifs des animaux.

capacités adaptatives / nutrition / reproduction / pérennité et durabilité des systèmes d'élevage

\section{INTRODUCTION}

The sustainability of livestock systems and their ability to adapt to new bioclimatic, technical or socio-economic contexts can be considered from two points of view. The first concerns the decisional component of the system, which drives elements of the biotechnical system towards short term objectives that are nevertheless consistent with long term strategies. The second considers that the ability of a livestock system to be perennial and respond to some of the challenges of sustainable development, closely depends on the animal adaptability [70]. This last point of view appears to be relevant for different livestock systems. In harsh areas the perennity of livestock farms depends on the capacity of the animals to survive and reproduce in situations of serious food restriction (drought, pastoral rearing in arid zones). In upland, wet or rough areas, it relies on their ability to maintain their performance levels (growth rates, milk production) while making an efficient use of low quality food resources they are incited to graze to answer to socio-economic challenges, like opening up areas suitable for leisure activities, maintaining fire-breaks, enhancing landscapes of value [44] and biodiversity [73]. In more intensive systems, female adaptabilities are also largely requested because of high reproductive rhythms and environmental constraints [74].

In such contexts, the sustainability of livestock farming systems and their ability to change depend on the potential of the animals to adapt to feeding constraints and biological rythms, and on the efficiency of the physiological (digestive, metabolic and hormonal) and behavioural regulations that are involved in coping responses.

The first objective of this review is to focus on the mechanisms at work in the adaptive processes. They are considered to have 
a significant impact on the productivity and the perennity of the livestock farming system since they will determine the ability of animals to maintain or not their production and reproductive functions. The second objective is to illustrate how the analysis of response profiles to an increased constraint is a way to assess the animals' adaptive potentials. Such an approach consists in quantifying the elasticity of the responses (range of response variation according to the variation of the constraint [9]) and in identifying disruption thresholds that reveal failures to adapt. This should lead to a more dynamic analysis of the animals' response in connection with the past, present and future variation of the level of constraint.

The review considers underfeeding as the constraint applied to the reproductive female. This animal model has been chosen because of its major contribution to the overall performance of the herd, and in relation to the role that females play in the perennity of the system through their reproductive function.

The review first focusses on the behavioural and physiological components of the adaptive response and defines the concepts of elasticity, rebound and failure to adapt (disruption). The interactions between nutrition and reproduction are then emphasised as they illustrate how two adaptive strategies (individual survival vs. maternal investisment) may coexist or confront each other according to the level of constraint. At last, the review focusses on the relationship between adaptability and longevity of females according to their genotype and the level of constraint.

\section{CAPACITIES OF FEMALES TO ADAPT TO THEIR ENVIRONMENT}

Any animal can be considered as a biological system placed in an environment in which it must carry out three essential and interdependent functions: to take in nutrients, to resist biotic (interspecific, intraspecific) and abiotic constraints and finally to disseminate its genes (fitness). These three functions rely on the expression of the behavioural repertoire of each species, as well as on the physiological functioning of the organism.

\subsection{Behavioural component of the adaptive response}

Nutrient intake by herbivores results from the expression of intake and feed selection behaviour. Herbivores are able to use heterogenous resources by developing selective grazing strategies which allow them to elaborate a diet of better nutritional value than what is available to them as a whole [2]. Food selection and intake behaviour depend on the interaction between the animal's characteristics (morpho-physiology, nutritional requirement level) and the nature of the available vegetation (availability, structure, nutritional value and palatability) $[7,63]$ ).

Under environmental constraints, behavioural adaptations can emerge. This has been reported with red deer hinds (Cervus elaphus) subjected to high stocking densities at pasture [8]. When the spatial constraint is severe, social tensions can be observed among fellow animals (increase of agonistic encounters, Fig. 1a) as inter-individual distances are reduced. When animals are held in small enclosures, subordinate individuals have less possibilities of escaping the aggressions of dominant individuals by fleeing and avoidance behaviour. When spatial dispersion is not possible, subordinate individuals may develop behavioural patterns that lead to spreading activities over time such as desynchronised or accelerated activity rhythms (increase of daily frequency of meals while reducing their 

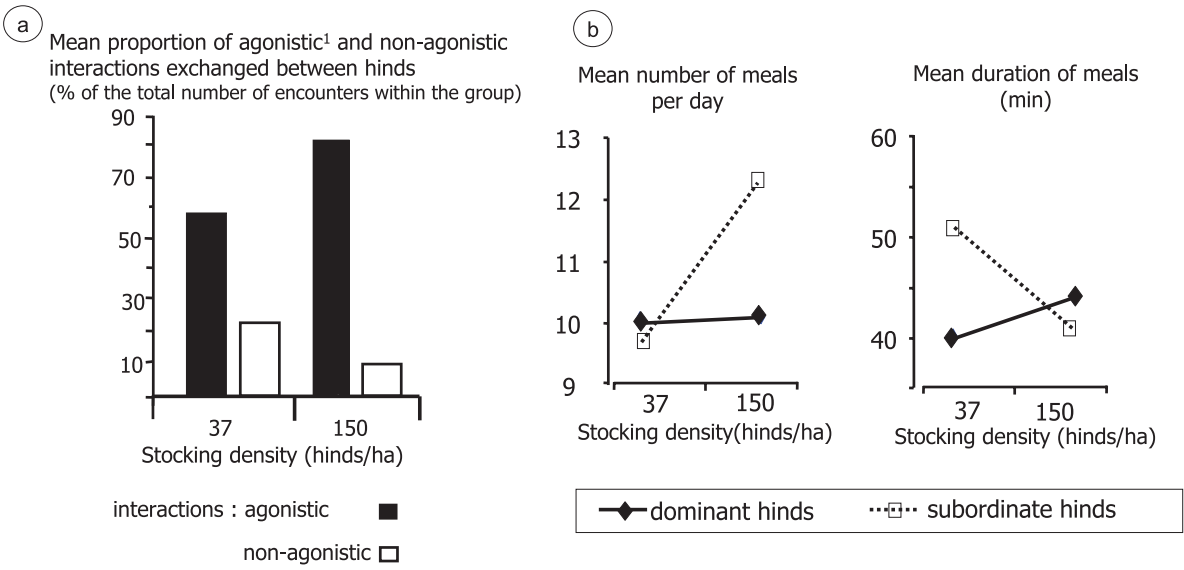

Figure 1. Effect of stocking density on the social and feeding behaviour of grazing red deer hinds (adapted from Blanc and Thériez [8]). ${ }^{1}$ Agonistic encounters were defined as occasions when one hind physically attacked another or made a ritualised gesture associated with attacks that caused the other animal to move away. They included 'mild' threats: ear threats, nose threats and displacements and severe threats: kicks, bites, butts, pushes and chases.

duration, Fig. 1b) [8]. Such behavioural coping strategies limit social tensions, at the same time enabling subordinate hinds to keep a total grazing time similar to that of dominant individuals. For the range of the spatial constraint studied, the profile of response to changes in grazing time can be qualified as inelastic [9]. Adaptive abilities of feeding and intake behaviour have also been studied in cattle managed in groups. In this species, many studies revealed that increasing social pressure (high density, heterogeneity of groups, high level of competition for food) induces a decrease in daily duration and synchronisation of eating, but a concomitant increase in the intake rate which helps to maintain the intake level of some individuals $[49,50]$.

Such an ability animals have to develop behavioural strategies to cope to a restricting environment makes it possible to envisage changes in practices, sometimes necessary to guarantee the perennity of the livestock system (increase in herd size for example) or even to enhance its impact on vegetation and its contribution to environ- mental objectives (open up woody areas by increasing grazing pressure for example).

\subsection{Characterisation of the physiological processes involved in the adaptive response to underfeeding}

In suckler farming systems, reproductive females are rarely fed at the level of their theoretical requirements all along their productive cycle. Feeding practices mostly consist of alternating underfeeding and refeeding periods. Feed restrictions can be more or less severe depending on the physical components of the environment (climate, vegetation, accessibility of food resource) or on the management decisions the breeder takes to reach production cost objectives. Whilst not ignoring the importance of other components such as animal health and product quality, the perennity of this livestock farming system is largely based on the animals' ability to adapt to nutritional constraints for more or less long periods. 


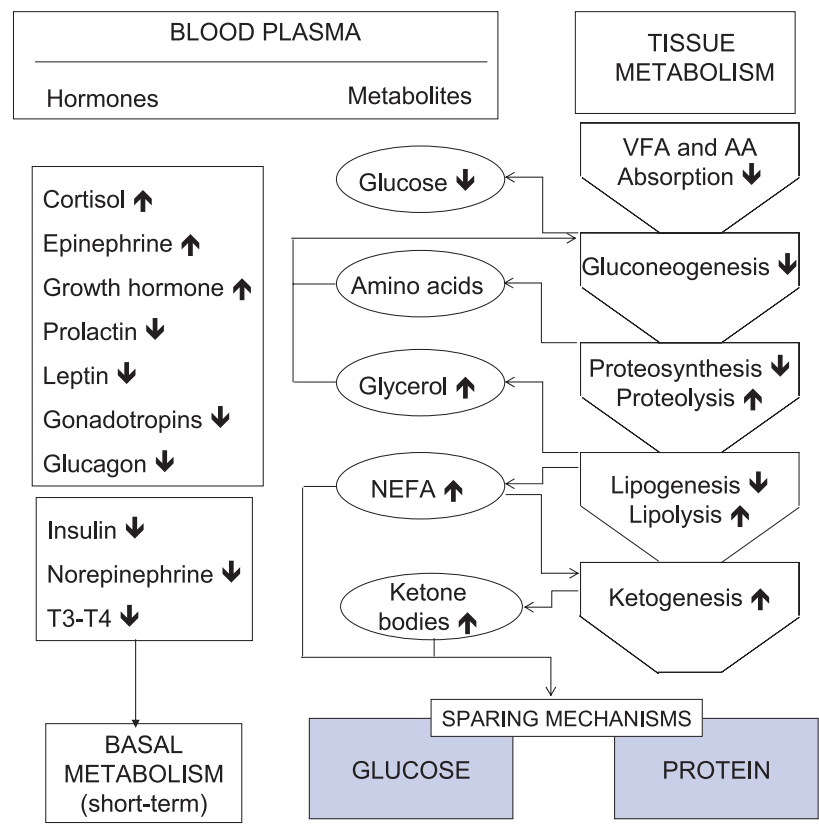

Figure 2. Metabolic and endocrine adaptations to undernutrition in the ruminant (from Chilliard et al. [26]). NEFA: non-esterified fatty acids, AA: Amino-acids, VFA: volatile fatty-acids, T3-T4: thyroid hormones.

The main effects of endocrinal and metabolic responses to inadequate nutritional requirements are to maintain homeostasis. Thus, underfeeding adaptations (Fig. 2) involve the coordinated and sequential mobilisation (short, medium and long term) of endogenous substrates such as those stored in the body reserves, then the establishment of mechanisms for saving limiting metabolites (glucose, amino acids) and finally, a reduction in the basic metabolism and energy expenditure (movements, walking). These homeostatic regulations are clearly activated when, for example, an animal at maintenance is foodrestricted $[3,17]$ in order to ensure its survival.

But outside this transitory state, in which the animal is at maintenance, farm animals, notably females, are usually in production. Two underfeeding situations can be distinguished [28]: the case where feed is not available in sufficient quantity (restricted feeding) to satisfy requirements (situation qualified as absolute underfeeding) and the case where feed is in sufficient quantity and quality (feed ad libitum), but its intake does not allow requirements to be satisfied (situation qualified as relative underfeeding).

This latter situation is frequently encountered in highly productive dairy females: at the beginning of lactation, requirements increase more rapidly than intake capacity [51]. During this period which lasts for several weeks (10 to 11 weeks in dairy cows), specific adaptive mechanisms are activated. They enable the animal to evolve towards a new nutritional state (positive energy balance) which is attained when intake once again enables requirements to be satisfied. The processes at work in this relative underfeeding situation follow an adaptive cascade which 
involves high mobilisation of lipids, and to a lesser degree, of body proteins. They allow supporting an increase in milk production whilst intake remains limiting [40]. In this particular case, the development of the digestive tract (weight and metabolism of the splanchnic tissues) operates independently of weight variations in other tissues and progressively allows voluntary intake to increase. The state of body reserves and the ability of the female to mobilise them at the start of lactation play an important role in the expression of dairy potential. But the loss of adipose mass at the start of lactation can be very variable insofar as the relative underfeeding level depends on the milk production level, the animal's appetite and the feed input level [24,25]. Nevertheless, a loss of 10 to $40 \%$ of adipose mass is classically observed during the first six weeks of lactation in cows and ewes. It can even reach $80 \%$ in animals in an underfeeding state [22]. Thus, females in poor body condition at parturition are particularly sensitive to the effects of underfeeding at the start of lactation $[4,21])$. Adipose reserves, which take account of the remanent effects of previous feeding conditions, and the female's ability to mobilise them at the start of lactation play a determining role in the expression of dairy potential and in the female's capacity to adapt to underfeeding in early lactation [32].

Situations of relative underfeeding can vary considerably depending on the nutritional strategies applied to the herd of females. Nutritional constraint can for example be reinforced by restricting feed at the start of lactation. In this case, analysing the responses of dairy females to underfeeding at the start of lactation [24, 25, 32] again demonstrates the cows' adaptive capacity, at least in the medium term. In the case of moderate under-feeding (85-90\% of energy requirements covered) for 4 to 11 weeks post-partum in the dairy female (cow, ewe), the reduction in energy exported in milk is less than the deficit in

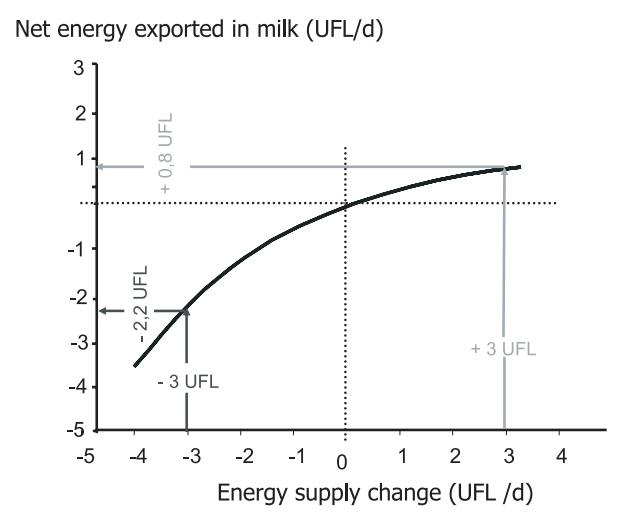

Figure 3. Effect of energy supply changes (UFL per day, 0 when supply equals requirements) on the energy exported in milk production of the dairy cow. The energetic conversion ratio was considered to equal 0.44 UFL per $\mathrm{kg}$ of milk (adapted from Coulon and Rémond [32]).

energy inputs (Fig. 3): the mobilised body energy contributes more than $30 \%$ to the energy exported by milk. When feeding restriction is maintained for a long period (between 18 and 40 weeks), the energy exported by milk reduces and adjusts to the actual energy intake [32]: adaptive responses diminish during lactation. The adaptive capacities allowed by the body reserves diminish too when animals are underfed during several consecutive lactations $[21,76]$.

When the animal is not at maintenance, the teleophoretic [20] regulations are active, coordinating the metabolisms by readjusting the set points of the homeostatic regulations $[6,23]$. These adaptations are such that the integrity of the organism can be maintained whilst at the same time supporting metabolic mobilisations for production and establishing saving and recycling mechanisms. At an energy level, they are expressed by an increase in the biological efficiency of certain functions. Thus, in the cow, adipose reserves are reconstituted more efficiently at the end of lactation (Net energy/Metabolisable energy $=0.60$ ) than 


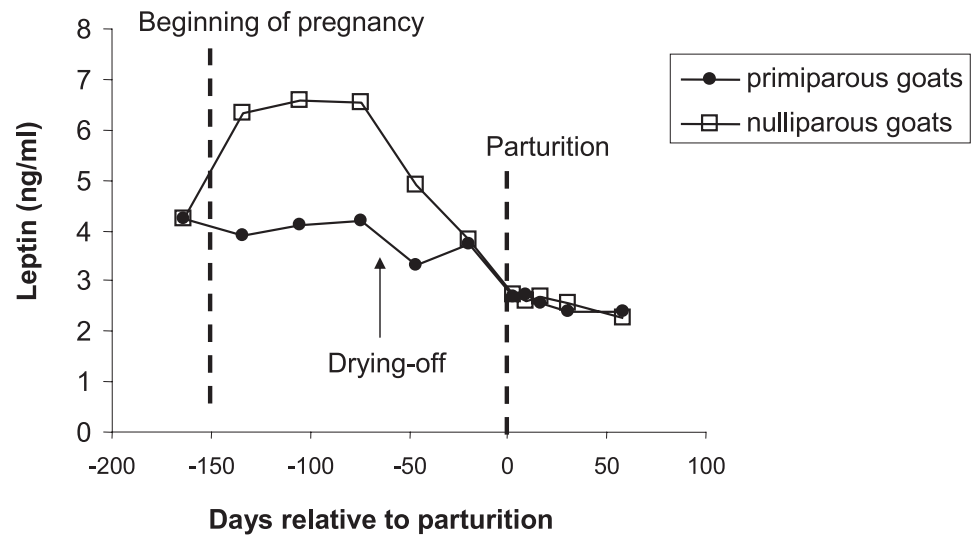

Figure 4. Effect of the pregnancy-lactation cycle on plasma leptin concentrations in nulliparous and primiparous goats (adapted from Bonnet et al. [18]).

during the dry period (0.40) [51], so that the energy deficit at the start of lactation can be partially compensated for by increased energy efficiency of the subsequent reconstitution [24]. This adaptation probably brings into play the endocrine and autocrine role of the adipose tissue, via the production of leptin, which is liberated proportionately to adiposity [34], and/or other adipokins. Leptinemia, whose short term nutritional regulation is significantly modulated by adiposity [31], could be an important energy efficiency regulator to be taken into consideration.

Thus, the more the mass of adipose tissue is reduced, the more the animal is stimulated to eat and rebuild its fat reserves. What is more, lactation reduces leptinemia even when the animal is in positive energy balance and in good body condition ([18]; Fig. 4), which could favour energy efficiency overall, whatever the stage of lactation [31]. Conversely, the "maintenance requirement" is higher in the fat cow [1] or ewe [30] than in the thin cow or ewe of the same frame size, probably linked to the stimulation of heat production by its increased leptinemia. Finally, at least in medium term, the impact of a given level of underfeeding will differ according to the animal's physiological state and according to its body condition when it undergoes this food restriction.

Most analytical studies on the regulation of animals' energy status have revealed that it is the result of a number of biological regulations which interfere with the different metabolisms (glucidic, proteic, lipidic). Although the enzymatic ways and the principal regulation processes (direct actions) are quite well described $[12,13,26,30]$, there are, however, numerous indirect regulatory ways that are expressed differently according to the physiological and environmental context $[12,13,27])$ and to individuals, which still remain unclear. This variety of response nevertheless appears to be a fundamental element of the animal's capacity to adapt to variable and contrasted nutritional situations.

\subsection{From saving to rebound: reactivity of the adaptive response}

Adaptive responses of compensation or rebound are observed when a period of refeeding succeeds a more or less sustained and severe phase of feed restriction. The 


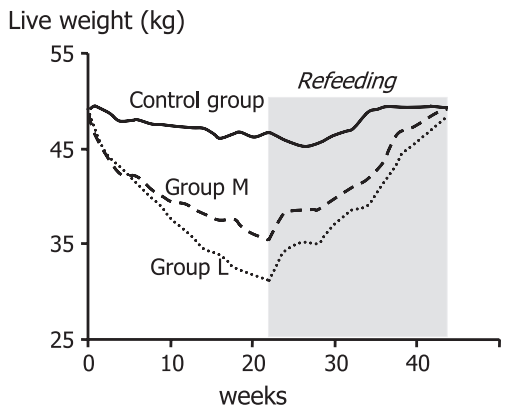

Figure 5. Long term adaptation of Barbarine ewes placed in two situations of food restriction: $40 \%$ (group M) or 20\% (group L) of requirements covered, then refeeding (150\% of energy requirements covered) (10 ewes per group) (adapted from Atti and Bocquier [3]).

most classic example of rebound response is that of the compensatory growth observed upon return to unlimited feed (grazing) after a period of feed restriction that mostly occurs in the winter [48]. The digestive and metabolic adaptations at work in this rebound period are effective in a few days [48], which demonstrates the reactivity of the organism to benefit from an improvement in the nutritional conditions.

The rebound process has also been stressed on adult females during their production cycle: ewes at maintenance [3], cows and goats in lactation [24]. It intervenes as much on the lipogenic activities of the adipose tissue as on the quantities of lipids stored. It is likely to induce significant differences of feed balance which have been demonstrated by comparing two long term feeding strategies applied to the Barbary ewe [3]. The stabilised strategy, which adjusts inputs to a level that maintains ewes at a constant weight (maintenance requirements for 45 weeks: control ewes), was compared with a dynamic strategy consisting of a severe underfeeding ( $40 \%$ or $20 \%$ of their energy requirements) for 22 weeks followed by refeeding (130 to $150 \%$ of requirements for their initial live weight (Fig. 5). Measurements showed that the body composition of ewes underfed then refed was identical to that of the control ewes [3]. Thus, in the dynamic strategy, total net energy inputs (156 UFL, i.e. 1108 MJ NEL) are 20\% lower than those recorded in the stabilised strategy (188 UFL, i.e 1336 MJ NEL). In terms of feed costs, the energy spared corresponds to 1.7 months of maintenance requirements. It can be interpreted by an increase in feed efficiency resulting directly from the mechanisms of mobilisation and saving implemented during the chronic underfeeding and refeeding periods $[12,13,26,27,30]$. Some of these processes involve modulation of energy efficiency via leptin or other adipocyte hormones secreted in a variable manner depending on adiposity [31].

The processes of saving and rebuilding of muscle and adipose tissues during underfeeding and refeeding are more or less efficient according to species, breed or age. Thus the Barbarine ewe is also able to mobilise its adipose tissues during underfeeding and to rebuild them during refeeding [30]. The Barbarine ewe also appeared to be able to rebuild the entire loss of muscular mass during refeeding [3]. Such a response differs in the dry not pregnant adult cow subjected to variable food levels over time: in the course of the refeeding period, dynamics of lipidic and proteic deposits differ and are characterised by an important growth of adipose tissues whilst recovery of the muscular mass remains limited $[55,65]$.

Such a profile of reconstitution of reserves is similar to that observed in humans (Fig. 6) and is interpreted according to Dulloo et al. [38], by a difference in the speed of lipid and protein deposition during the refeeding phase. To take account of rapid fat reserve recovery without modifying the speed in depositing proteins during refeeding, a model is proposed $[38,45,46]$ in which the efficient deposit of adipose reserves depends on the filling state of the 


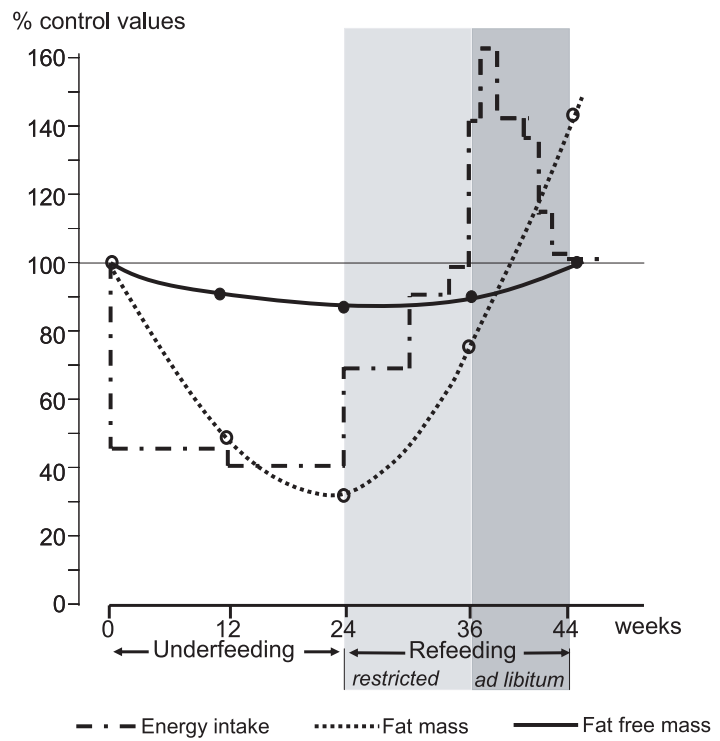

Figure 6. Pattern of changes in energy intake, body fat and fat-free mass during underfeeding and refeeding in humans $(n=12)$. All values are expressed as a percentage of corresponding values during the period previous to feeding restriction (adapted from Girardier [46]).

lipid storage compartment. Such a model helps to predict in man, the variations in body composition after refeeding and describes the change in body composition of subjects when they return to their initial weight following the semistarvationrefeeding cycle. At this final state, subjects are fatter than they were at the beginning. At the stage when body fat is completely recovered, fat-free mass is still below the control value.

In terms of adaptive potential, such a mechanism based on the development of highly efficient energy saving can be considered as an important survival factor in a context where the energy resource is cyclical and submitted to random influences (climate variability). However, long term feed management favouring a succession of underfeeding/refeeding cycles is likely to induce a progressive deterioration of the muscular mass of the organism if refeeding does not last long enough, to allow the proteins to recover completely. Such an evo- lution may be a problem in man (successions of underfeeding periods associated with shortages in certain countries, treatment by some slimming diets for obesity associated with overabundance or unbalanced diet in others), it is less so in livestock females whose lifetime is relatively short (a few years).

\subsection{Disruptive situations: the limits of biological regulation systems}

Some production systems and associated management practices, make considerable calls on the animals' adaptive abilities, for they are characterised by an accumulation of constraints on the animal: an increase in animal density and/or in group size, stimulus-poor environments, artificialisation of some biological processes such as suckling and reproduction [16]. We have previously illustrated that the animal's capacity to adapt to 
the increasing constraints of its environment is partly based on the implementation of behavioural responses. However, the emergence of highly adaptive behavioural strategies is limited to the range of the behavioural repertoire of each species. Thus, seriously frustrating situations can lead to failure to adapt [16].

Two approaches are presently being developed to improve the animals' behavioural abilities to adapt to their livestock environment. The first focusses on actions on the livestock environment to make it less constrictive for the animal [74]. The second intervenes directly on the animal to modulate the manner in which it may experience environmental events, either by acting on its own history (response to stressful events occuring at a more or less early stage [66]), or by selecting animals on the basis of desired emotional profiles [16]. This second strategy aims at directing the adaptive abilities of individual animals according to the constraints specific to the production system. Although it can prove effective for a given livestock system, it is at risk for its perennity if breeding conditions change: in fact rapid and significant modifications of the surroundings correspond to a new set of constraints which can be very different from the environment for which the animals were selected. They may then no longer be capable of developing sufficiently effective adaptive behaviour in changing environments.

Disruptive situations are also observed as regards physiological responses. Relative underfeeding levels applied to dairy cows (about $-10 \%$ of total requirements, or more in a tropical environment) are generally lower than those that may be confronted by dairy sheep in a Mediterranean zone. As in the dairy cow, during serious energy underfeeding, the mobilisation of adipose reserves enables the ewe to a certain extent to continue producing milk. In the Lacaune ewe, as long as the en-

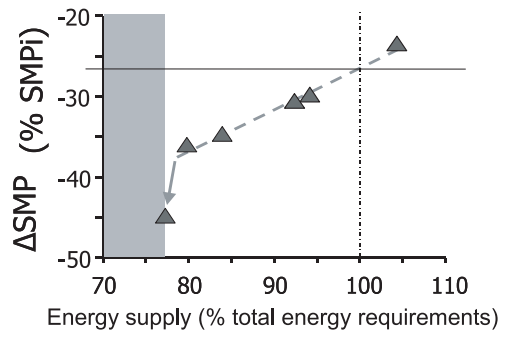

Figure 7. Changes of the standardised milk production (SMP, expressed in percentage of initial milk production SMPi), in relation to the level of energy feed supply (\% of total energy requirements) in Lacaune dairy ewes. Each point represents the mean response of 12 ewes (adapted from Bocquier et al. [14]).

ergy deficit does not exceed $20 \%$ of total energy requirements, the milk production linearly declines (reduction relative to the initial dairy production) with the energy supply (Fig. 7). On the contrary, when the energy supply goes below $80 \%$ of the requirements, the fall in milk production is dramatic [14]. This fall accounts for a disruption in the homeostatic balance, characterised by a serious reduction in the insulin circulating rates in ewes that are severely underfed.

This situation arises frequently in livestock where animals are herd-managed. In fact, the diversity of production levels and physiological states within a large herd, fed in a single way, can cause disruption situations in some sensitive individuals [11]. Sensitive animals are those which, taking into account the available food resources and their intake capacity, will not be able to satisfy their requirements. Within a herd, the proportion of sensitive animals depends not only on the variability of nutritional requirements (physiological stage, production level) and the diet value (bulk, nutritional value), but also on the hierarchical status of the individuals (dominant, subordinate). Nevertheless, in dairy ewes, feeding strategies can be set up to 
limit such disruptive situations in sensitive individuals. In this way, a collective diet does not usually lead to a problem when the ration is calculated to satisfy the requirements of at least $80 \%$ of the individuals [11]. When the breeder has productive animals but poor quality forage, satisfying $80 \%$ of the individuals' requirements implies using concentrates which will not be valorised by low-producing animals. To avoid such a waste, the only solution is to divide the herd into groups of homogenous animals according to their production level. If, however, it is accepted that some animals adapt (downwards) their production levels to the value of the diet, the system becomes less demanding in terms of inputs and to this extent satisfies more sustainability issues. Synchronising nutritional requirements within a herd is a risky practice when the production factors are not very well-controlled (feed in particular) and when animals may be placed in a situation of adaptive disruption during their production cycle. So it seems that, for livestock systems in which reproduction periods are not well controlled and the physiological stages of the animals are dispersed, the adaptive capacity of the herd considered as a whole may be greater than that of a cohort of individuals with a narrow range of nutritional requirements [5].

\section{CENTRAL ROLE OF RELATIONSHIP BETWEEN NUTRITION AND REPRODUCTION FOR THE PERENNITY OF THE HERD IN A SITUATION OF NUTRITIONAL CONSTRAINT}

The reproductive function is a key animal component of the productivity of livestock farming systems. Numerous studies have emphasised the sensitivity of this biological function to the nutritional status of the female. The effects of nutrition on the ability to reproduce can be observed at different phases of the female's productive life: at a young age via its effects on the onset of puberty, then in adult females by its impact on the fertility rate (and on prolificacy) and therefore on the reproductive rhythm. More particularly, the role of energy balance and the mobilisation of adipose reserves have clearly been demonstrated (reviews of Butler [19] for the dairy cow, of Diskin et al. [37] for the suckler cow) and have led to approaches for integrating and formalising the processes at work. Thus, Friggens [43] developed a conceptual framework where body lipid reserves vary with time through the reproductive cycle and are the link between the cyclic nature of reproductive priorities and strategies for dealing with environmental constraints. The relationship between the female's nutritional state and reproductive function is very particular, because the energy requirements for reproduction per se, i.e. ovulation and conception, are practically negligible. On the contrary, initialising a pregnancy has heavy consequences for the survival of the female if nutritional inputs and/or its body reserves are insufficient. Indeed, its requirements will increase during pregnancy and above all, after the start of lactation. This means that, at the level of the individual female, reproductive priorities between the current and the next offspring may change over time and according to the nutritional status of the female.

The regulation of reproduction by the nutritional status therefore supposes, at a given time, the implementation of mechanisms for simultaneously evaluating the energy balance and the state of the adipose reserves. Such an evaluation, at key phases of the reproductive process (days following calving in the dairy cow), could be a way of assessing the commitment of the female to a new pregnancy, thus limiting the risk associated with reproduction [19, 23]. To summarise [43], the rate of energy 
mobilisation at the reproductive period is then seen as a monitor of current environmental conditions, whereas body fatness is proposed as an indicator of ability to withstand future environmental constraints and manage the risk to invest in a new reproductive cycle. The ability of the dam to support the demands of future offspring in a constrained environment will thus largely depend on the size of her body reserves. Such processes are advantageous for the animal to maintain flexibility in resource allocation and be able to cope with nutritional constraint.

The physiological mechanisms at work in the management of reproductive priorities between the current and the future offspring appear to be very complex and are still not understood [19]. Hormones such as insulin and leptin are considered to play a role in the control of reproduction [68]. Leptinemia (and other signals from adipose tissues) probably intervenes since it is linked both to the level of reserves and to the present nutritional status (cf. above), and it seems able to limit reproduction when it is below a threshold of about 4 to 5 ng per mL (Fig. 8; [47,57,61]). Two possible ways of control are suggested in the literature. One considers that leptin (and/or insulin) could directly mediate the effects of energy metabolism on the reproductive axis, the other supposes that leptin could modulate the availability of metabolic fuels in the brain or periphery (Schneider [68]).

\subsection{The effects of the nutritional status of females on their survival and their reproductive investment depend on the dynamic of the production cycle}

Environmental constraints, in particular those related to food availability, the level of technical and technological control, and the biological peculiarities of the species are reasons for a variety of reproduction
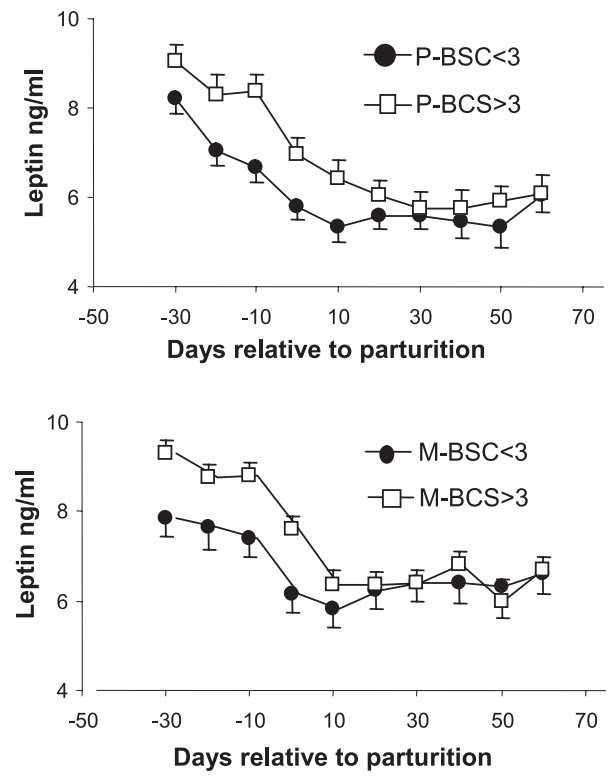

Figure 8. Concentration of leptin (least squares means $\pm \mathrm{SEM})$ in lean $(\mathrm{P}-\mathrm{BCS}<3)$ and fat $(\mathrm{P}-$ $\mathrm{BCS} \geq 3$ ) primiparous cows and lean (M-BCS $<$ 3) and fat (M-BCS $\geq 3$ ) multiparous cows (BCS = body condition score) (adapted from Meikle et al. [61]).

management methods [72]. Thus, in an extreme situation, in South Senegal (Kolda), the reproductive pattern of N'Dama cows is characterised by great intervals of time between reproductive events, with an average age at first parturition of 5 years and an average calving interval of 2.3 years [39]. On the contrary, in herds in a temperate climate, reproduction patterns are often close to the theoretical biological limits of the species: calving interval close to one year or even 3 lambings in 2 years in a suckler sheep flock.

In the first case (rather insecure systems), the adaptive capacities of livestock systems rely principally on the animal component. The biological regulations, namely the balances between homeostasis and productive functions (teleophoresis), determine the dynamics of reproductive 
events and the survival of females. These balances lead to variable reproduction rhythms and long time steps. The analysis of these patterns [39] shows that reproduction is only effective when a sufficient body condition coincides in time with favourable nutritional conditions. Another important element in these Sub-Saharan pastoral systems is the decision to cull females that not always directly depends on their ability to reproduce, since a live animal is considered as a financial capital to be maintained as a priority and at the lowest cost. Consequently, the survival of females within such a system mainly depends on the animal's ability to adapt to environmental conditions and particularly to underfeeding.

In intensive livestock systems, high reproductive rhythms are sought (using hormonal treatments) and practices of feeding, replacement, and culling support and orientate the reproductive performances of females, as well as their survival. For species characterised by long reproductive cycles (i.e. cattle), as well as for those with short but accelerated cycles (i.e. sheep), reproductive patterns tend to be very close to physiological limits $[33,56]$. In fact, intervals between successive parturitions impose very short resting periods. Thus, biological regulations of the different functions are highly stimulated and work interdependently because of the rapid succession or even overlap of different physiological states. So these regulations can lead to disruptive states after which one of the functions associated with reproduction (fertility, milk production) is altered. Such a response can then be interpreted, for the breeder, as insufficient adaptive abilities of the animal, and for the female, as a strategy to survive. Insofar as females unable to adapt to such accelerations in rhythm are usually culled, physiological processes favouring the survival of the individual to the detriment of its investment in the following generation, are not activated in such intensive systems. High milking dairy cows are particularly sensitive to this risk of culling because, selected for their milk production level, they are less able to reproduce in the conditions desired by the livestock farmer (a negative genetic correlation of -0.3 is observed between milk production level and fertility at first artificial insemination; [15]). In this context, it appears useful to understand the interaction between nutrition and reproduction to avoid disruption situations or functional blockage (anoestrus).

\subsection{Characterisation of the interrelationships between nutrition and reproduction}

The effects of nutrition on the reproductive efficiency of females have been widely studied in suckler farming systems. These studies are particularly instructive when we focus on the question of the perennity of the system insofar as suckling systems are based on a maximum use of forage resources. The animals concerned may therefore often be subjected to very long, intense phases of food restriction. Studies emphasise the effects of food restriction not only on the physiological characteristics of reproductive function, but also on the sexual behaviour of females.

In dairy and suckler cattle systems in temperate zones, nutrition $\times$ reproduction interactions come into play mainly in the days following calving, during the acyclic period that follows calving [69]. An increase in the postpartum anoestrus duration in relation with low body condition at calving was observed in our experimental farms: food supply during the winter has more influence on the length of postpartum anoestrus than on overall fertility in cattle [62]. Thus, a one point decrease below the mean body condition score induced a 10-day delay in the resumption of ovarian activity in multiparous cows and a 20day delay in primiparous cows [62]. The 
female therefore clearly invests in a new production cycle, but at a slower rhythm. This is particularly the case of primiparous cows whose growth function (including protein metabolism; [75]) interacts with lactation and reproduction functions. This has notably been observed in dairy farming systems with a parity $\times$ growth hormone treatment interaction on reproduction (review of [29]) and body reserves [64], and a parity $\times$ body condition at calving interaction on reproduction [61].

Physiological mechanisms at work in regulating the reproductive function linked to the nutritional status of cows have recently been the subject of bibliographical reviews [19,37]. In the suckler cow, moderate but prolonged food restriction (60 to $70 \%$ of satisfied requirements) is accompanied by a progressive reduction in growth of the dominant ovarian follicle and its persistence. If this underfeeding is prolonged in such a way that live weight losses exceed $20 \%$ of the initial weight, the animals go into a state of nutritional anoestrus [37]. This response nevertheless shows very high interindividual variability whose causes can be multiple (genetics, age, parity and adiposity). These disruptive situations (nutritional anoestrus) can also be observed in the case of very severe food restrictions. Severe underfeeding (40\% of requirements satisfied in the animal at maintenance) of short duration is accompanied by a rapid decrease in growth rate and maximum diameter of dominant follicles. It induces anoestrus in a high proportion of individuals $(60 \%)$ in the 15 days following the start of food restriction $[37,59]$. Observation of such differences in follicle development dynamics and ovulation between the studies of chronic and acute dietary restriction suggests that the physiological response to undernutrition may be related to a threshold below which the effects on follicle development are rapid. This threshold seems to lie in the range between 40 and $60 \%$ of maintenance require- ments [37]. Such a response is interpreted as a disruptive situation in which the individual's survival function becomes a priority and is developed to the detriment of commitment to the following generation.

Rebound type responses are to be found alongside these disruption phenomena. They account for a temporary increase in the system's efficiency during underfeeding/refeeding sequences. Thus, female lambs undergoing severe food restriction after weaning show significant delays in the initiation of puberty, even a durable blockage of the reproductive function [42]. Refeeding was observed to induce the onset of puberty within a few weeks in ewe lambs whose puberty was previously inhibited by food restriction [41].

Recent observations lead us to suppose that interactions between nutrition and reproduction not only play at a physiological level but also at a behavioural one. Indeed, ewe lambs that were severely underfed from weaning to 8 months of age all reached puberty (increase in progesterone concentrations over $1 \mathrm{ng}$ per $\mathrm{mL}$ ) after a 3 week refeeding period, but only $40 \%$ of them expressed oestrous behaviour [10]. Thus, even if the effects of food restriction on sexual behaviour have been relatively little studied in ruminants, it is suggested that oestrous behaviour is a way of regulating the female's response to underfeeding. Maintaining ovarian functioning (not very costly), while inhibiting sexual behaviour may allow a minimisation of the risk of fertilisation in a situation of uncertainty for food availability, at the same time ensuring high reactivity in the system if the food situation becomes more favourable. Such reactivity seems to depend on the animals' body condition at the time of refeeding because, as for leptinemia where response to overfeeding depends on the adiposity level [30], some limitations may exist in animals that are too lean, as suggested by the non response of LH pulsatility to refeeding in 
these animals [28]. As long as a disruption threshold has not been reached, the system might be able to react rapidly thanks to the continuation of underlying ovarian activity and to a behavioural regulation which may temporarily block oestrus expression. Further investigations are needed to validate such a hypothesis.

\section{ADAPTIVE RESPONSES TO UNDER-FEEDING: CONSEQUENCES ON THE LENGTH OF THE PRODUCTIVE CAREER AND INFLUENCE OF THE GENOTYPE}

In a steady state livestock system (with a constant number of reproductive females), the female replacement rate largely determines their productive lifetime within the herd (longevity). For the farmer, this rate must be optimised because rearing young females for replacement represents high breeding costs. As soon as these females join the adult group, the farmer's interest is to keep them, provided that there is no economic depreciation on the cull carcass. The productivity of females must therefore be evaluated globally over their complete lifetime. One work carried out in the suckler cattle system has clearly demonstrated the interaction that exists between the adaptive potential of cows placed in underfeeding situations and the duration of their productive lifetime. The comparison focussed on the responses of two cattle breeds, Salers and Limousine, reared and managed according to two feeding levels (High vs. Low) from weaning to fourth lactation [36]. Differences in feeding levels between the High and Low groups were operated from mid-August to the end of April, first of all using the stocking rate at grazing, then during the winter, the cows in the High groups were fed according to their requirements, whilst the energy re- quirement cover rate of the Low groups was $80 \%$. Only one period of ad libitum grazing, lasting 3.5 months, was common to all the animals.

During the winter period, underfeeding had no effect on the average milk production of the primiparous and multiparous Salers cows $(-0.5 \mathrm{~kg}, \mathrm{~ns})$, whilst it did affect milk production of the Limousines ( -1.0 to $1.5 \mathrm{~kg}, P<0.01$; Fig. 9).

After ad libitum grazing, the milk production of cows in the Low groups increased (Limousines), and even significantly exceeded (multiparous Salers) those of previously better fed cows (Fig. 9). The differences between Salers and Limousine response profiles can be interpreted either by larger adipose reserves (at maturity) that are more easily mobilised in the Salers, or by differences in grazing intake levels.

Whilst in the Salers, the difference of $50 \mathrm{~kg}$ live weight observed at first calving between the two feeding levels remained unchanged after four lactations, the same initial difference entirely disappeared in the Limousines, without observing any drift linked to the cull policy (the distribution of live weights of culled cows in the two breeds was identical to that of the cows retained) (Fig. 10). Such results can be interpreted in the following way: the Salers cow gives priority to producing milk for its calf growth, then for new pregnancies (maternal investment), whilst the Limousine continues to grow and store reserves for itself (survival of the individual). As regards the reproductive function, the Salers cows also appeared less sensitive to underfeeding [35]. In fact, the difference in duration of post-partum anoestrus observed between animals in the High and Low groups was lower in the Salers than in the Limousines. Furthermore, there was a breed $\times$ parity interaction in accordance with the greater sensitivity of primiparous previously reported (respectively -7 vs. -12 days for multiparous and -15 vs. -43 days for primiparous). Over the long 


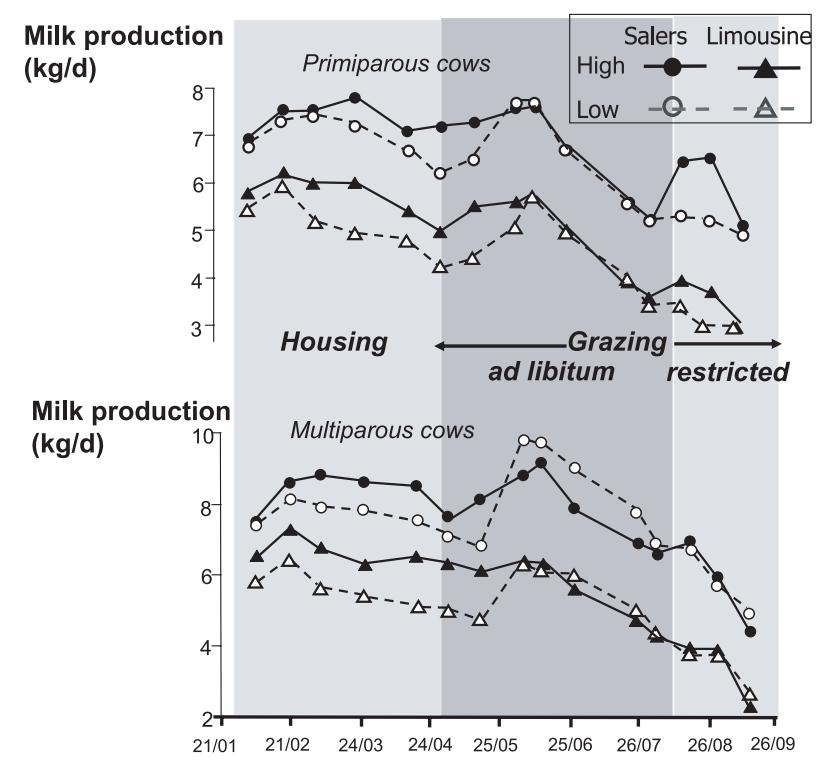

Figure 9. Change over time, depending on parity, of the milk production Salers $(\bullet, \bigcirc)$ and Limousine $(\boldsymbol{\Lambda}, \triangle)(n=127)$ cows exposed to two feeding levels in the winter: High (energy requirements covered) or Low ( $80 \%$ of energy requirements covered in the winter) (adapted from D'Hour et al. [36]).

term, after four lactations in a situation of food restricted resources, a difference in capacity to adapt between breeds emerged. This had direct effects on the cows' survival rate (Fig. 11), which resulted from a culling policy based mainly on the elimination of empty females (reproductive failure during the breeding period).

In suckler systems, interactions between productive and reproductive abilities have often been measured in order to select the best genotypes in a given environment. Some studies analysed the differences in adaptive responses between genotypes in a non-optimal situation and accounted for how these adaptive potentials could modify the productivity and efficiency of the system. In the suckler cow, the response curves describing the production level according to various food constraint levels differ according to breeds [52]. For some genotypes (group 1: Charolais, Limousin,

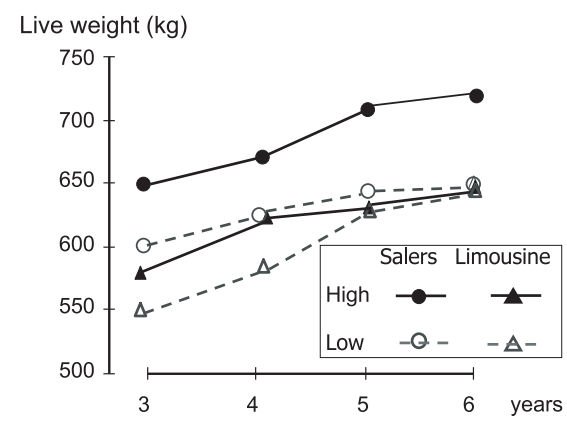

Figure 10. Change over time of the live weights of Salers $(\bullet, 0)$ and Limousine $(\boldsymbol{\Lambda}, \triangle)$ cows exposed to two feeding levels in the winter: High (energy requirements covered) or Low (80\% of energy requirements covered in the winter) (adapted from D'Hour and Petit [35]).

Simmental), the production level linearly increased with the feeding level, whilst for others (group 2: Angus, Red Poll, Hereford), the productivity curve went via 


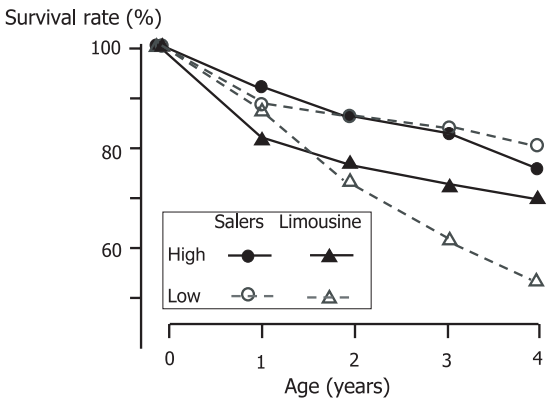

Figure 11. Change over time of survival rates of Salers $(\boldsymbol{\bullet}, 0)$ and Limousine $(\boldsymbol{\Delta}, \triangle)$ cows (\% of cows remaining in the herd) exposed to two feeding levels in the winter: High (energy requirements covered) or Low (80\% of energy requirements covered in the winter) (D'Hour and Petit [35]).

an optimum (Fig. 12). Thus the breeds in group 2 had higher productivity ( $\mathrm{kg}$ of weaned calf per reproductive cow) in a situation of food restriction. On the contrary, when inputs increased, their productivity became comparable to, or even lower than, that of breeds in group 1 . The biological efficiency of breeds in group 2 (breeds qualified as early maturing) diminished when food conditions became favourable, insofar as the growth potential of their calves was lower than that of calves from breeds in group 1 (late maturing breeds).

The notion of early sexual maturity designates the ability of an animal to rapidly establish its adipose tissues to reach a given maturity rate. This concept is not only used to discriminate response profiles between breeds, but also to characterise the responses of individuals within a same breed. In the Retinta cow reared in a semi-arid Mediterranean environment, a positive correlation has been observed [58] between the precocity of females and their productivity (total weight of weaned calves), whilst this correlation was negative for Red Poll females reared in more favourable feeding conditions [60]. Such results indicate that the choice of genotype determines

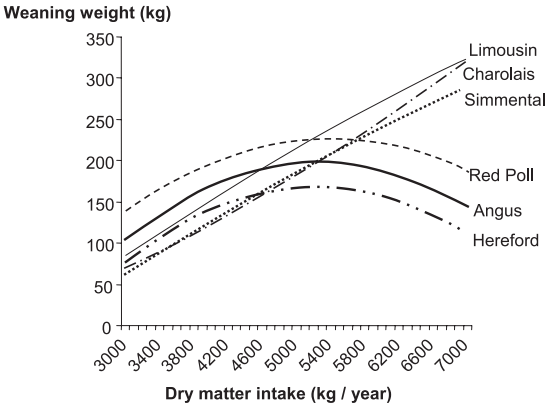

Figure 12. Predicted weight of calves weaned per cow exposed at varying dry matter intakes for nine breeds of cattle (adapted from Jenkins and Ferrell [52]).

the adaptive potential of the animals and has an influence on the sensitivity of the farming system to increasing feed constraint $[52,53]$. The concept of precocity leads moreover to envisaging the regulation processes between production and reproduction functions over the long term and in association with the dynamics of body development (evolution of weight and body composition) in the growing animal.

\section{CONCLUSION}

The model of the reproductive female reared in a restrictive nutritional environment reveals that, according to the livestock farming systems, the adaptive response that gives priority to the individual survival before maternal investment, may not be efficient in some livestock farming systems. If this strategy contributes to the perennity of the herd in systems that face very severe food restriction periods by depressing fertility and avoiding futile maternal investment [43], it paradoxically appears to challenge the survival of individuals in most livestock farms in temperate zones, because of the pressure of culling on unproductive females or on females whose reproductive activity is 
simply delayed. Consequently, abilities of animals to accommodate to environmental constraints have to be considered in reference to a given context and any generalisation to quite different systems should be questioned.

However, rearing animals adapted to changes is a real issue of finalised research that aims at proposing durable and sustainable farming systems in various environments. Such an approach is already developed in order to find out more about animals' response variations according to their genotype $[53,54]$ and to identify the response profiles that allow better adaptive potentials to appear. Comparative approaches are interesting to quantify the response of different genotypes or different types of animals (primiparous vs. multiparous) to a variation of a single constraint. They reveal if a type is more able to adapt and/or to produce throughout different levels of a studied constraint. These approaches may, however, fail to predict what will be the animals' response within a new scale of constraint levels or under a new set of constraints.

Since we emphasised that the question of the sustainability of livestock systems partly refers to the question of the ability of animals to adapt to changes in practices or in the environment, it would make sense to think of how to predict adaptive responses to various management decisions. An interesting way could be to use metaanalyses that allow to integrate knowledge and quantify the response from the findings from a collection of studies $[67,71]$.

To understand how behavioural and physiological adaptations operate during the lifespan of the animal, it is necessary to rely on biological knowledge of adaptations in domestic animals. It may be quite easy to conceive the interest of homeostatic regulations for the survival of an animal at maintenance, but it is more difficult to predict the effects of teleophoretic regulations which are partic- ularly active in animals selected on their production level. These teleophoretic dynamics, directed firstly towards conception then the survival of the young, are developed under the dependence of physiological (metabolic, hormonal) and behavioural regulation processes which also tend to guarantee the survival of the female itself (homeostasis). In these two types of adaptation (survival of the individual and survival of the species) body reserves appear to play a fundamental role in restoring the energy balance. The study of animal adaptation to undernutrition emphasises the existence of regulatory processes which seem to reveal a real capacity for anticipation and nutritional risk management. The mechanisms implied in this aptitude to anticipate are unknown. In the same way little is known about the incidence of the past nutritional trajectories of females on their aptitude to invest in a new productive cycle in relation to their nutritional status at the time of reproduction. Thus, future research should investigate a more dynamic approach of adaptive processes. Systemic modelling appears to be helpful to take account of the processes in their dynamic dimension and makes it possible to conceive memorisation phenomena likely to induce variations in the animals' medium and long term productive trajectories. Such a prospect is clearly suggested by Girardier [46] who stated from studies on the body composition dynamics in man that "the ultimate control of energy balance would not bear on the homeostasis of a state of body composition but rather on its dynamic stability. This is giving a historical dimension to the system, some sort of memory of past conditions which will affect its further evolution".

\section{REFERENCES}

[1] Agabriel J., Petit M., Recommandations alimentaires pour les vaches allaitantes, 
Bull. Tech. CRVZ Theix INRA 70 (1987) 153-166.

[2] Agreil C., Fritz H., Meuret M., Maintenance of daily intake through bite mass diversity adjustment in sheep grazing on heterogeneous and variable vegetation, Appl. Anim. Behav. Sci. 91 (2005) 35-56.

[3] Atti N., Bocquier F., Adaptation des brebis Barbarine à l'alternance sous-nutrition réalimentation : effets sur les tissus adipeux, Ann. Zootech. 48 (1999) 189-198.

[4] Atti N., Nefzaoui A., Bocquier F., Influence de l'état corporel à la mise bas sur les performances, le bilan énergétique et l'évolution des métabolites sanguins de la brebis Barbarine, Opt. Méd. Sér. A 27 (1995) 25-33.

[5] Atti N., Bocquier F., Khaldi G., Performance of the fat-tailed Barbarine sheep in its environment: adaptive capacity to alternation of underfeeding and refeeding periods. A review, Anim. Res. 53 (2004) 165-176.

[6] Bauman D.E., Vernon R.G., Effects of exogenous bovine somatotropin on lactation, Annu. Rev. Nutr. 13 (1993) 347-461.

[7] Baumont R., Prache S., Meuret M., MorandFehr P., How forage characteristics influence behaviour and intake in small ruminants: a review, Livest. Prod. Sci. 64 (2000) 15-28.

[8] Blanc F., Thériez M., Effects of stocking density on the behaviour and growth of farmed red deer hinds, Appl. Anim. Behav. Sci. 56 (1998) 297-307.

[9] Blanc F., Bocquier F., Agabriel J., D'hour P., Chilliard Y., Amélioration de l'autonomie alimentaire des élevages de ruminants : conséquences sur les fonctions de production et la longévité des femelles, Renc. Rech. Ruminants 11 (2004) 155-162.

[10] Blanc F., Fabre D., Bocquier F., Canepa S., Delavaud C., Caraty A., Chilliard Y., Debus N., Effects of a postweaning restricted nutrition on the initiation of puberty, plasma leptin and the reproductive performances of early-bred Merino ewes lambs. 11th Seminar of the Sub-Network FAO-CIHEAM on sheep and goat nutrition, Opt. Méd. (2006) in press.

[11] Bocquier F., Guillouet Ph., Barillet F., Alimentation hivernale des brebis laitières: intérêt de la mise en lots, INRA Prod. Anim. 8 (1995) 19-28.
[12] Bocquier F., Ferlay A., Chilliard Y., Effects of body lipids and energy balance on the response of plasma nonesterified fatty acids to a beta-adrenergic challenge in the lactating dairy ewe, in: McCracken K., Unsworth E.F., Wylie A.R.G. (Eds.), Energy Metabolism of Farm Animals, CAB International, Wallingford, UK, 1998, pp. 167-173.

[13] Bocquier F., Bonnet M., Faulconnier Y., Guerre-Millo M., Martin P., Chilliard Y., Effects of photoperiod and feeding level on adipose tissue metabolic activity and leptin synthesis in the ovariectomized ewe, Reprod. Nutr. Dev. 38 (1998) 489-498.

[14] Bocquier F., Caja G., Oregui L.M., Ferret A., Molina E., Barillet F., Nutrition et alimentation des brebis laitières, Opt. Méd. Sér. B 42 (2002) 37-55.

[15] Boichard D., Barbat A., Briend M., Évaluation génétique des caractères de fertilité femelle chez les bovins laitiers, Renc. Rech. Ruminants 5 (1998) 103-106.

[16] Boissy A., Fisher A.D., Bouix J., Hinch G. N., Le Neindre P., Genetics of fear in ruminant livestock, Livest. Prod. Sci. 93 (2005) 23-32.

[17] Bonnet M., Leroux C., Faulconnier Y., Hocquette J.F., Bocquier F., Martin P., Chilliard Y., Lipoprotein lipase activity and mRNA are up-regulated by refeeding in adipose tissue and cardiac muscle of sheep, J. Nutr. 130 (2000) 749-756.

[18] Bonnet M., Delavaud C., Rouel J., Chilliard Y., Pregnancy increases plasma leptin in nulliparous but not primiparous goats while lactation depresses it, Domest. Anim. Endocrin. 28 (2005) 216-223.

[19] Butler W.R., Energy balance relationships with follicular development ovulation and fertility in postpartum dairy cows, Livest. Prod. Sci. 83 (2003) 211-218.

[20] Chilliard Y., Revue bibliographique : Variations quantitatives et métabolisme des lipides dans les tissus adipeux et le foie au cours du cycle gestation-lactation. 1 . Chez la ratte, Reprod. Nutr. Dev. 26 (1986) 1057-1103.

[21] Chilliard Y., Physiological constraints to milk production: factors which determine nutrient partitioning, lactation persistency, and mobilization of body reserves, World Rev. Anim. Prod. (1992) 19-26. 
[22] Chilliard Y., Metabolic adaptations and nutrient partitioning in the lactating animal, in: Martinet J., Houdebine L.M., Head H.H. (Eds.), Biology of lactation, Collection Mieux Comprendre, INRA Éditions, Paris, FRA, 1999, pp. 503-552.

[23] Chilliard Y., Bocquier F., Direct effects of photoperiod on lipid metabolism, leptin synthesis and milk secretion in adult sheep, in: Cronjé P.B. (Ed.), Ruminant physiology: digestion, metabolism, growth and reproduction, $\mathrm{CAB}$ International, Wallingford, UK, 2000, pp. 205-223.

[24] Chilliard Y., Rémond B., Sauvant D. Vermorel M., Particularités du métabolisme énergétique, Bull. Tech. CRZV Theix INRA 53 (1983) 37-64.

[25] Chilliard Y., Rémond B., Agabriel J., Robelin J., Vérité R., Variations du contenu digestif et des réserves corporelles au cours du cycle gestation lactation, Bull. Tech. CRZV Theix INRA 70 (1987) 117-131.

[26] Chilliard Y., Bocquier, F., Doreau M., Digestive and metabolic adaptations of ruminants to undernutrition, and consequences on reproduction, Reprod. Nutr. Dev. 38 (1998) 131-152.

[27] Chilliard Y., Ferlay A., Després L., Bocquier F., Plasma non-esterified fatty acid response to a beta-adrenergic challenge in underfed or overfed, dry or lactating cows, before or after feeding, Anim. Sci. 67 (1998) 213-223.

[28] Chilliard Y., Doreau M., Bocquier F., Les adaptations à la sous-nutrition chez les herbivores, Cah. Nutr. Diét. 33 (1998) 217-224.

[29] Chilliard Y., Colleau J.J., Disenhaus C., Lerondelle C., Mouchet C., Paris A., L'hormone de croissance recombinante : intérêt et risques potentiels de son utilisation pour la production laitière bovine, INRA Prod. Anim. 11 (1998) 15-32.

[30] Chilliard Y., Ferlay A., Faulconnier Y., Bonnet M., Rouel J., Bocquier F., Adipose tissue metabolism and its role in adaptations to undernutrition in ruminants, Proc. Nutr. Soc. 59 (2000) 127-34.

[31] Chilliard Y., Delavaud C., Bonnet M., Review. Leptin expression in ruminants: nutritional and physiological regulations in relation with energy metabolism, Domest. Anim. Endocrin. 29 (2005) 3-22.
[32] Coulon J.B., Rémond B., Variations in milk output and milk protein content in response to the level of energy supply to the dairy cow: a review, Livest. Prod. Sci. 29 (1991) 31-47.

[33] Cournut S., Dedieu B., A discrete events simulation of flock dynamics: a management application to three lambings in two years, Anim. Res. 53 (2004) 383-403.

[34] Delavaud C., Ferlay A., Faulconnier Y., Bocquier F., Kann G., Chilliard Y., Plasma leptin concentration in adult cattle: Effects of breed, adiposity, feeding level, and meal intake, J. Anim. Sci. 80 (2002) 1317-1328.

[35] D'hour P., Petit M., Influence of nutritional environment on reproductive performances of Limousin and Salers cows, in: Pullar D. (Ed.), Suckler cow workers meeting, Kirbymoorside, UK, 1997, pp. 15-18.

[36] D'hour P., Petit M., Pradel P., Garel J.P., Évolution du poids et de la production laitière au pâturage de vaches salers et limousines dans deux milieux, Renc. Rech. Ruminants 2 (1995) 105-108.

[37] Diskin M.G., Mackey D.R., Roche F., Sreenan J.M., Effects of nutrition and metabolic status on circulating hormones and ovarian follicle development in cattle, Anim. Reprod. Sci. 78 (2003) 345-370.

[38] Dulloo A.G., Jacquet J., Girardier L., Autoregulation of body composition during weight recovery in human: the Minnesota Experiment revisited, Int. J. Obesity 20 (1996) 393-405.

[39] Ezanno P., Ickowicz A., Bocquier F., Factors affecting the body condition score of N'Dama cows under extensive range management in Southern Senegal, Anim. Res. 52 (2003) 37-48.

[40] Faverdin P., Bareille N., Lipostatic regulation of feed intake in ruminants, in: van der Heide D., Huisman E.A., Kanis E., Osse J.W.M., Verstegen M. (Eds.), Regulation of Feed Intake, Wageningen, Netherlands, 1999, pp. 89-102.

[41] Foster D.L., Olster D.H., Effect of restricted nutrition on puberty in the lamb: patterns of tonic luteinizing hormone (LH) secretion and competency of the LH surge system, Endocrin. 116 (1985) 375-381.

[42] Foster D.L., Yellon S.M., Olster D.H., Internal and external determinants of the timing of puberty in the female, J. Reprod. Fertil. 75 (1985) 327-344. 
[43] Friggens N.C., Body lipid reserves and the reproductive cycle: towards a better understanding, Livest. Prod. Sci. 83 (2003) 219236.

[44] Gibon A., Managing grassland for production, the environment and the landscape. Challenges at the farm and the landscape level, Livest. Prod. Sci. 96 (2005) 11-31.

[45] Girardier L., L'auto-régulation du poids et de la composition corporelle chez l'homme. Une approche systémique par modélisation et simulation, Arch. Int. Physiol. Biochim. Biophys. 102 (1994) A23-A35.

[46] Girardier L., Body energy store management during fasting and recovery: a systemic approach, in: Guy-Grand B., Ailhaud G. (Eds.), Prog. Obesity Res. (John Libbey \& Company Ltd) 8 (1999) 467-481.

[47] Giuliodori M., De La Sota R.L., Formia N., Chilliard Y., Delavaud C., Becu-Villalobos D., Lacau-Mendigo I.M., Leptin level increases before post-partum first ovulation in dairy cows, Biotech. Agron. Soc. Environ. 8 (2004) 45 .

[48] Hoch T., Begon C., Cassar-Malek I., Picard B., Savary- Auzeloux I., Mécanismes et conséquences de la croissance compensatrice chez les ruminants, INRA Prod. Anim. 16 (2003) 49-59.

[49] Ingrand S., Agabriel J., Lassalas J., Dedieu B., How group feeding influences intake level of hay and feeding behaviour of beef cows, Ann. Zoot. 48 (1999) 435-444.

[50] Ingrand S., Comportement alimentaire, quantités ingérées et performances des bovines conduits en groupe, INRA Prod. Anim. 13 (2000) 151-163.

[51] INRA (Institut National de la Recherche Agronomique), Alimentation des bovins, ovins et caprins, in: Jarrige R. (Ed.), INRA, Paris, 1988, $476 \mathrm{p}$.

[52] Jenkins T.G., Ferrell C.L., Productivity through weaning of nine breeds of cattle under varying feed availabilities: I. Initial evaluation, J. Anim. Sci. 72 (1994) 2787-2797.

[53] Jenkins T.G., Ferrell C.L., Efficiency of feed utilization of diverse biological types of cattle, in: Proceedings of the 7th World Congress on Genetics Applied to Livestock Production, Montpellier, France, 2002, pp. 285-288.
[54] Jenkins T.G., Ferrell C.L., Preweaning efficiency for mature cows of breed crosses from tropically adapted Bos indicus and Bos taurus and unadapted Bos taurus breeds, J. Anim. Sci. 82 (2004) 1876-1881.

[55] Laurenz J.C., Byers F.M., Schelling G.T. Greene L.W., Periodic changes in body composition and in priorities for tissue storage and retrieval in mature beef cows, J. Anim. Sci. 70 (1992) 1950-1956.

[56] Lee G.J., Atkins K.D., Prediction of lifetime reproductive performance of Australian Merino ewes from reproductive performance in early life, Aust. J. Exp. Agr. 36 (1996) $123-128$.

[57] Liefers S.C., Veerkamp R.F., te Pas M.F.W., Delavaud C., Chilliard Y., Van der Lende T., Leptin levels in relation to energy balance, milk yield, dry matter intake, liveweight, and fertility in dairy cows, J. Dairy Sci. 86 (2003) 798-807.

[58] Lopez de Torre G., Candotti J.J., Reverter A., Bellido M.M., Vasco P., Garcia L.J., Brinks J.S., Effects of growth curve parameters on cow efficiency, J. Anim. Sci. 70 (1992) 2668-2672.

[59] Mackey D.R., Wylie A.R.G., Sreenan J.M., Roche J.F., Diskin M.G., The effect of acute nutritional change on follicle wave turnover, gonadotropin, and steroid concentration in beef heifers, J. Anim. Sci. 78 (2000) 429-442.

[60] Marshall T.E., Mohler M.A., Stewart T.S., Relationship of lifetime productivity with mature weight and maturation rate in Red Poll cows, Anim. Prod. 39 (1984) 383-387.

[61] Meikle A., Kulcsar M., Chilliard Y., Febel H., Delavaud C., Cavestany D., Chilibroste P., Effects of parity and body condition at parturition on endocrine and reproductive parameters of the cows, Reprod. 127 (2004) 727-737.

[62] Petit M., Agabriel J., État corporel des vaches allaitantes Charolaises : signification, utilisation pratique et relations avec la reproduction, INRA Prod. Anim. 6 (1993) 311-318

[63] Prache S., Gordon I.J., Rook A.J., Foraging behaviour and diet selection in domestic herbivores, Ann. Zootech. 47 (1998) 335-345.

[64] Rémond B., Cissé M., Ollier A., Chilliard Y., Slow release somatotropin in dairy heifers 
and cows fed two levels of energy concentrate. 1. Performance and body condition, J. Dairy Sci. 74 (1991) 1370-1381.

[65] Robelin J., Agabriel J., Malterre C., Bonnemaire J., Changes in body composition of mature dry cows of Holstein, Limousin and Charolais breeds during fattening. Skeleton, muscles, fatty tissues and offal, Livest. Prod. Sci. 25 (1990) 199-215.

[66] Roussel S., Hemsworth P.H., Boissy A., Duvaux-Ponter C., Effects of repeated stress during pregnancy in ewes on the behavioural and physiological responses to stressful events and birth weight of their offspring, Appl. Anim. Behav. Sci. 85 (2004) 259-276.

[67] Sauvant D., Schmidely P., Daudin J.J., Les méta-analyses des données expérimentales : applications en nutrition animale, INRA Prod. Anim. 18 (2005) 63-73.

[68] Schneider J.E., Energy balance and reproduction, Physiol. Behav. 81 (2004) 289-317.

[69] Short R.E., Bellows R.A., Staigmiller R.B., Berardinelli J.G., Custer E.E., Physiological mechanisms controlling anestrus and fertility in postpartum beef cattle, J. Anim. Sci. 68 (1990) 799-816.

[70] Sinclair K.D., Agabriel J., The adaptation of domestic ruminants to environmental constraints under extensive conditions, Ann. Zootech. 47 (1998) 347-358.
[71] St-Pierre N.R., Invited review: Integrating quantitative findings from multiple studies using mixed model methodology, J. Dairy Sci. 84 (2001) 741-755.

[72] Tichit M., Ingrand S., Dedieu B., Bouche R., Cournut S., Lasseur J., Moulin C.H., Le fonctionnement du troupeau : une interaction entre la conduite de l'éleveur et les comportements reproductifs d'animaux, Renc. Rech. Ruminants 9 (2002) 103-106.

[73] Tichit M., Durant D., Kernés E., The role of grazing in creating suitable sward structures for breeding waders in agricultural landscapes, Livest. Prod. Sci. 96 (2005) 119-128.

[74] Veissier I., Capdeville J., Sarignac C., A partir de quelles bases peut-on concevoir des bâtiments respectueux du bien-être des animaux de rente, Renc. Rech. Ruminants 5 (1998) 273-279.

[75] Vérité R., Chilliard Y., Effect of age of dairy cows on body composition changes throughout the lactation cycle as measured with deuteriated water, Ann. Zootech. 41 (1992) 118.

[76] Wiktorsson H., General plane of nutrition for dairy cows, in: Broster W.H., Swan H. (Eds.), Feeding strategy for the high yielding dairy cow, Granada, Publ. Ltd, 1979, pp. $148-170$. 